\title{
A cost- benefit analysis of routes between the Trans-Korean and Trans-Siberian railways
}

\author{
Anna Eremina* and Chan-Hyun Sohn**
}

\begin{abstract}
Recently the route connecting the trans-Korean railway and the trans-Siberian railway has become of particular interest for many academics and policy-makers in East Asian countries. The extensive review of previous studies, however, reveals that literature on the subject is lacking solid analytical framework. Most studies are one-sided, focusing on the political aspects of the issue or paying little attention to the economic aspects of the problem.

This study intends to develop an analytical framework through which the most efficient route among four major alternative routes connecting the trans-Korean and trans-Siberian railways can be identified. It attempts to assign priorities to the four alternative routes according to their level of economic efficiency.

This study utilizes a simple cost-benefit analysis in evaluating the four routes. Cost side, transportation time, effectiveness of customs procedures, and gauge difference are selected as the main economic factors. The volume of cargo, industrial production in adjacent regions, access to natural resources, and market size and foreign investment climate are used to evaluate the benefits of the routes.

The study concludes that Route 3, which connects 'Busan - Seoul (South Korea)-Pyongyang Sinuiju (North Korea)-Shenyang-Beijing - Erenhot (China) - Ulaanbaatar (Mongolia)-Ulan-Ude Moscow (Russia)' is the most efficient route.
\end{abstract}

Keywords: trans-korean railway, trans-siberian railway, route selection JEL classification: F13, F15

Submission Date: $10 / 28 / 2010$

Revision Date: 11/12/2010

Acceptance Date: $11 / 20 / 2010$

* Student, Department of International Trade and Business, Kangwon National University

${ }^{* *}$ Corresponding author, Professor, Department of International Trade and Business, Kangwon National University, Chuncheon 200-701 Korea. e-mail: chsohn@kangwon.ac.kr.

The authors would like to thank Professors Won Jung Kim and Hyun-Hoon Lee for their helpful comments. This study was supported by a 2007 research grant from Kangwon National University. 


\section{Introduction}

World trade has grown rapidly during the last two decades. The trade between Europe and East Asia has been no exception. In fact, it has expanded faster than most world trade.

The growing international trade volume between East Asia and Europe engendered an important question, namely, "Wouldn't it be promising to develop a new overland-route that could bring East Asia and Europe closer?" In this regard, connecting the trans-Korean and trans-Siberian railways becomes of particular interest for policy-makers, businesses and academic researchers.

The historic summit between the leaders of South and North Korea in June 2000 at Pyongyang initiated the movement to restore the rail link between the two parts of the Korean peninsula. Later Russia also expressed the intention to link the trans-Korean railway to its trans-Siberian railway. These successive moves accelerated discussions on the effects they might bring and the alternative routes connecting the two railways.

The All-water-route has long been the most popular transportation choice for consignors of South Korea, Japan, China and other East Asian countries in delivering their goods to European counterparts. The newly connected overland rail network is expected to be a strong competitor and to undoubtedly substitute much of the all-water-route and other multimodal routes being currently used for the East Asia-Europe cargo transportation.

Recently Balalaev, et al. (2008) highlighted the expected benefits coming from the reconstruction of the trans-Korean railway and its connection to the trans-Siberian main line. The connection is expected to reduce shipping time. It will take only 13-18 days to deliver goods from South Korea to Europe compared to 30-40 days which are required for the same delivery along the all-water-route. In addition, the connection will reduce logistics costs by $75 \%$ and will increase East Asia-Europe trade by 400 million US dollars. The connection may also ease political and military tension on the Korean Peninsula thereby facilitating greater stability in the whole Asia-Pacific region.

The significant economic and political effects of the connection resulted in several alternative routes. Among them, four routes are the most widely reviewed and suggested in the official documents of UNESCAP as well as preceding studies. Figure 1 shows the detailed courses of the four major routes that connect Busan, Korea to Moskow, Russia. The Remaining way to Europe is supposed to utilize the current Russian railway route: 


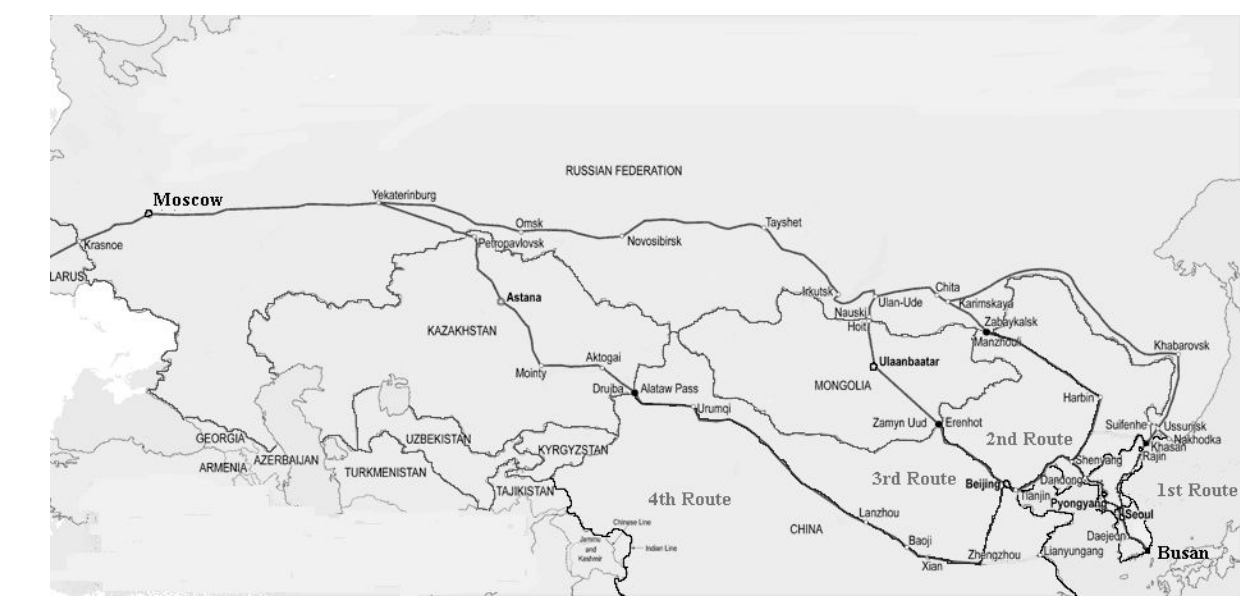

Source: UNESCAP

Figure 1.

Four Alternative Routes for the Trans-Korean and Trans-Siberian Railways Connection

Route 1 directly connect the trans-Korean railway with trans-Siberian main line. Route 2 goes through the trans-Korean, trans-Manjurian, then trans-Siberian railways. Route 3 links the trans-Korean to the rans-China, the trans-Mongolia, and finally the trans-Siberian railway. Route 4 goes through the trans-Korean and trans-China to the west, then through the trans-Kazakhstan and trans-Siberian railways. All four routes connect Busan, South Korea to Moscow, Russia and usually use Finland or Poland as an entrance into Europe.

Although very promising economic effects are expected from the railway connections, the issue has remained largely uncultivated. Researches on the issue are very sporadic and most analyses focus on one aspect of the issue: the technical or political aspect. Very few papers deal with economic analysis. Economic analyses are, furthermore, usually one-sided: They only assess either the cost side,e.g., transportation time or the benefit side, e.g., the size of consignment of the routes, not both sides simultaneously.

The objective of this paper is simple and straightforward: It is to identify the most efficient route among the four alternative routes in connecting the trans-Korean and trans-Siberian railways. In doing so, this study attempts to develop a systematic economic analytical framework in which different railway routes can be evaluated in both cost and benefit fronts. Based on extensive review of relevant literature, this paper selects the most critical factors for the cost and benefit sides. Furthermore, as the cost is measured by transportation time while the benefit is measured by the value of cargo, a new method is needed. This paper introduces the method for a simple cost-benefit comparison.

This paper is organized as follows: Section II reviews existing research on the trans-Korean and trans-Siberian railway connections. The determining factors for the cost 
and benefit sides are selected from comprehensive review of previous research. Section III presents the estimation of cost-benefit factors of the four alternative routes. The selection of the best route is given in Section IV. Here special attention is given to compare costs and benefits of routes that are in different units. Section $\mathrm{V}$ concludes the paper.

\section{Literature Review}

There have been a number of studies on the issue of trans-Siberian and trans-Korean railway connections. However, the studies are rather sporadic and scattered around in Korea, Japan, China and Russia.

Most of the research has been done since the year 2000, which is quite understandable given the date of the historical summit between North and South Korea. The leaders of the two Koreas announced the decision to restore the railway line between the two parts of the peninsula. This political move made the connection of the trans-Korean and trans-Siberian railways a feasible project and thereby called for the studies.

For the measurement of the effectiveness of a railway route, many previous studies selected 'transportation time' as one of the most important criteria for the determination of route competitiveness. The selection of transportation time for the measurement of efficiency of a route seems straightforward: The shorter it takes to deliver a consignment from its origin to its destination, the cheaper the cost for transportation. $\mathrm{Na}$ (2004) emphasized that the effective connection of railway systems is expected to result in large reductions in logistics expenses by shortening transportation distance and time. Tsuji (2004), Hausman (2005), Djankov (2005), Nordas, et al. (2006), Bardal (2007), Huziyatov (2008) and Hummels (2009) highlighted the importance of the transportation time variable in the route selection process. The Russian researchers, Bardal (2007) and Huziyatov (2008), similarly employed the transportation time variable into the analysis of the effectiveness of transportation routes. $\mathrm{Na}$ (2004) and Lee (2004) focused on the importance of 'timeliness of delivery' when considering transportation cost and route effectiveness. Brooks (2008) also agreed in selecting timeliness of delivery as an important factor in determining the cost effectiveness of railway routes.

The second most widely cited criteria suggested in the proceeding literature is the cross-border factor, particularly 'the number of border-crossings' and 'the effectiveness of customs procedures.' Tsuji (2004) argued that a bigger number of border-crossing points along the route would lower its overall efficiency. This is because any border-crossing will cause a delay in rail traffic for at least several hours according to Huziyatov (2008). In addition, the effectiveness of border-crossing procedures differs from country to country. Each country has different systems of customs procedures the each border-crossing. Countries that have advanced customs systems such as electronic documentation, specialized inspection 
systems, computerized customs procedures, mutually recognized technical standards, etc. require shorter custom procedures. however, border-crossing will take longer in countries with less-developed customs systems, official red -tape and/or corruption. As such, the more inefficient customs procedures are, the longer required to complete the border-crossing. Whiteing and Menaz (2009) specified that border-crossing delays are a major factor impeding the timeliness and cost-effectiveness of international rail freight movement and therefore the complexity of border-crossing procedures affects the route selection process.

The technical aspect of connecting the trans-Korean and trans-Siberian railways has also been investigated in the preceding research. Tennenbaum (2001), Tsuji (2004), Na $(2004,2007)$ and Huziyatov (2008) raised the significance of 'gauge difference' along the routes. Countries have different gauge systems traditionally. Some countries use a standard gauge system, whereas others use a narrow or a broad gauge railway system. Any difference of the gauges along a railway route requires transshipment which is time-consuming and costly in most cases. While Tennenbaum (2001) and $\mathrm{Na}$ (2004) provided other ways to overcome the gauge-difference of a route, all proved to be very costly.

The three factors mentioned so far basically deal with the cost side of railways. The cost side represents the total days and hours that are needed to deliver a consignment from its origin to its destination. In this study the origin and the destination are Busan, Korea and Moscow, Russia, respectively. The impact of the aforementioned cost factors on route competitiveness is unquestionable; therefore they should be taken into consideration when determining the best connecting route.

There are other factors that deal with the benefit side of connecting the railways. The most widely cited factor of the benefit side is 'the size of cargo' which directly represents total sales of each railway route. Tsuji (2004) and Huziyatov (2008) commented on the importance of the cargo in determining the efficiency of routes. In particular, Huziyatov included the cargo estimation of all possible routes for the linkage of the trans-Korean with the trans-Siberian main line. As such the size of cargo remains the most significant criteria in determining the efficiency of railway routes.

For the measurement of cargo, Abramov, et al. (2002), Park (2006) and Uyunayev (2008) paid special attention to industrial production along railroads. The existence of production plants in comparative proximity to the route is expected to contribute to the growth of cargo volumes. Cargo volume is created by additional uploading and unloading operations along the route.

Abundant natural resources along railway routes can increase cargo volume as well. Mining and agricultural productions are the most popular outcomes of natural resources. The extent of 'the access to natural resources' was examined in the works of Lee J.Y. (2004), Brooks (2008) and Balalaev, et al. (2008) as an additional beneficial factor that affects the size of cargo. Park (2006, p.62), in particular, stated that Route 1, the trans-Korean railway which directly connects to the trans-Siberian main line at Rajin-Hasan, will boost the 
development of the mining industry in the Far East and Russia, taking into account its abundant natural resources.

In order to estimate the size of cargo more accurately, some other factors are also suggested. Three scholars, Lee (2004), Brooks (2008) and Nekhoroshkov (2009) highlighted 'the market size and investment climate' for an additional benefit side factor . The bigger market size and larger investment along the railway route can encourage further increase of the cargo size.

The review of literature on the connection of the trans-Korean and trans-Siberian railways shows that most research focuses on the cost side and particularly on the transportation time in evaluating the efficiency of routes. There are two main reasons: First, research is scattered around in countries like Korea, Japan and Russia. In particular a lot of significant Russian research has not been reviewed or examined thoroughly by Korean and Japanese studies. Extensive review of Russian studies is more or less missing. ${ }^{1}$ Second, there has been no research that tries to select the most efficient route in connecting the railways. Most previous research has concentrated on only one side effect of the railway connection; either cost or benefit. This study considers both aspects. ${ }^{2}$

As one of the objectives of this study is to develop a comprehensive and systematic economic analytical framework, both aspects are needed. Table 1 summarizes the factors of both the cost and benefit sides of the railway connections that are to be used in the analysis. The cost side factors encompass not only the transportation time but the effectiveness of customs procedures, cross-border factors, and gauge differences as well. The benefit side includes industrial production of the region, access to natural resources, market size, investment climate, and cargo volume as well.

\footnotetext{
${ }^{1}$ One of the contributions of this paper is the extensive review of related Russian literature. It has been possible as the co-author is Russian.

2 This is the first paper that has attempted to find out the most effective route among the four alternatives. Thus a balanced approach based on both cost and benefit sides is of critical importance.
} 


\section{Table 1.}

Cost and Benefit Side Factors

\begin{tabular}{|c|c|c|c|}
\hline Cost Side Factors & Works & Benefit Side Factors & Works \\
\hline \multirow[t]{2}{*}{ Transportation time } & \multirow{2}{*}{$\begin{array}{l}\text { Tsuji (2004) } \\
\text { Lee J.Y. (2004) } \\
\text { Hausman (2005) } \\
\text { Djankov (2005) } \\
\text { Nordas et al.(2006) } \\
\text { Bardal (2007) } \\
\text { Na (2004, 2007) } \\
\text { Brooks(2008) } \\
\text { Huziyatov (2008) } \\
\text { Hummels(2009) }\end{array}$} & Amount of cargo & $\begin{array}{l}\text { Tsuji(2004) } \\
\text { Huziyatov (2008) }\end{array}$ \\
\hline & & Industrial production & $\begin{array}{l}\text { Abramov et al.(2002) } \\
\text { Park (2006) } \\
\text { Uyanaev (2008) }\end{array}$ \\
\hline $\begin{array}{l}\text { Effectiveness of } \\
\text { customs procedures } \\
\text { and cross-border factor }\end{array}$ & $\begin{array}{l}\text { Tsuji (2004) } \\
\mathrm{Na}(2004) \\
\text { Whiteing and Menaz } \\
\text { (2009) }\end{array}$ & $\begin{array}{l}\text { Access to natural } \\
\text { resources }\end{array}$ & $\begin{array}{l}\text { Lee J.Y. (2004) } \\
\text { Park (2006) } \\
\text { Brooks (2008) } \\
\text { Balalaev et al.(2008) }\end{array}$ \\
\hline Gauge difference & $\begin{array}{l}\text { Tennenbaum (2001) } \\
\text { Tsuji (2004) } \\
\mathrm{Na}(2004,2007) \\
\text { Huziyatov (2008) }\end{array}$ & $\begin{array}{l}\text { Market size and } \\
\text { Investment climate }\end{array}$ & $\begin{array}{l}\text { Chufrin (2003) } \\
\text { Lee J.Y. (2004) } \\
\text { Brooks(2008) } \\
\text { Nekhoroshkov(2009) }\end{array}$ \\
\hline
\end{tabular}

Most of the work on the connection of the trans-Korean and trans-Siberian railways has addressed technical or political aspects of the issue, save a few studies. ${ }^{3}$ An economic evaluation of the railway connections has been largely missing. A comprehensive systematic analytical framework with which to analyze the economic effects of the railway connection, however, has not been introduced. In short, the economic analyses on the effects of connections along the trans-Korean and trans-Siberian railways have not been fully cultivated yet. To accomplish this, researchers need to develop a rigorous analytical framework in which both cost side and benefit side effects of the railway connections are incorporated.

To properly address the problem of route selection with the purpose of building an economic analytical framework, this paper synthesizes all the findings discovered in preceding studies. The first thing that this paper did is to classify the factors into the cost side of the transportation process and the benefit side of the consignment as is seen in this Section.

3 Tsuji (2004), Na (2004) and Huziyatov (2008) correspond to this category. They have made the biggest contributions to the current body of research. 


\section{Estimation of Cost and Benefit Factors}

\subsection{Cost Factors}

The cost side of a connected railway can be most easily perceived by the total delivery time of transporting consignments from Busan, South Korea to Europe. As the railway from Moscow, Russia to Europe, e.g. Helsinki, Finland or Warsaw, Poland, remains the same, comparison of the four different routes is done simply by determining the total delivery time from Busan to Moscow. Map 1 shows the detailed courses of Routes 1 4 that link the trans-Korean railway to the trans-Siberian railway as follows:

Route 1: Busan - Seoul (South Korea) - Wonsan - Rajin - Tumangang (North Korea) - Khasan - Ussuriysk - via TSR - Moscow (Russia)

Route 2: Busan - Seoul (South Korea) - Sinuiju (North Korea) - Dandong - Shenyang - Harbin -Manzhouli (China) - Zabaikalsk - Chita - via TSR - Moscow (Russia)

Route 3: Busan - Seoul (South Korea) - Sinuiju (North Korea) - Dandong - Shenyang - Beijing - Erenhot (China) - Zamyn-Uud - Ulaanbaatar (Mongolia) Naushki - Ulan-Ude - via TSR - Moscow (Russia)

Route 4: Busan - Seoul (South Korea) - Sinuiju (North Korea) - Dandong - Shenyang - Beijing - Zhengzhou - Xian - Lanzhou - Urumuqi (China) - Alashankou Druzhba - Astana - Petrovavl (Kazakhstan) - Yakaterinburg - via TSR Moscow (Russia)

The total delivery time consists of transportation time, time needed for customs clearance, and time to adjust gauge difference as seen in Table 1. All these cost factors can be estimated in 'days and hours' taken.

The total delivery time is a complex concept comprised of several variables, which contribute to its final value. Among those are: (1) distance between the starting point and the point of destination; (2) train speed and/or its average daily run rate; and (3) time for additional procedures occurring during the process of cargo transportation.

According to Anikin (2002, p.274), the total delivery time can be estimated by the formula applicable to the rail transport:

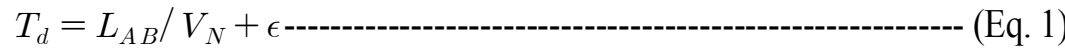

$$
\begin{aligned}
& \text { where, } T_{d}=\text { total delivery time(days); } \\
& L_{A B}=\text { distance between points } \mathrm{A} \text { and } \mathrm{B}(\mathrm{km}) \\
& V_{N}=\text { average daily run rate }(\mathrm{km} / \text { day }) \\
& \epsilon=\text { time for additional procedures (days) }
\end{aligned}
$$




\section{(1) Transportation Time}

The transportation time is measured by the first term of the right-hand side of (Eq. 1), which is $\mathrm{LAB} / \mathrm{VN}$. The ratio is calculated by total distance of the railway divided by the average speed of the train. Thus it represents the total number of days and hours needed to travel along the railway. In order to estimate the transportation time for each of the four alternative routes, the system of technical parameters is applied. The results are presented in Table 2.

According to Table 2, Route 1, which is a direct linkage of trans-Korean railways with the trans-Siberian main line, proved to be the most effective in terms of transportation time. It takes only 9.8 days to deliver cargo from Busan to Moscow. This result can be explained by the dominant use of the trans-Siberian railway, which consists of $87.8 \%$ of the whole route and has the most efficient average daily run rate among the five railways. The speed of express container trains on the trans-Siberian railway is about 1,200 kilometers per day which is far higher than other railways. ${ }^{4}$

The second most efficient route is Route 2, which goes via the trans-Manchurian railway (China) and Trans-Siberian railway. Cargo transportation along this route would take one day longer than via Route 1. Route 3 takes almost three days longer than Route 1 due to the less efficient Trans-Mongolian railway, comprising 11\% of the whole route. It is because the Trans-Mongolian has only single-track lines. Route 4 proved to be the longest one among four taking 19.2 days. The trans-China railway comprises more than $50 \%$ of the route and has the lowest average daily run rate, which explains the comparatively low time efficiency of Route 4.

\footnotetext{
${ }^{4}$ Russian railways, 2009: www.rzd.ru
} 
Table 2.

Calculation of Transportation Times for the Four Alternative Routes.

\begin{tabular}{|c|c|c|c|c|}
\hline \multirow[t]{2}{*}{ Route } & \multirow[t]{2}{*}{ Section } & $\begin{array}{c}\text { Transit distance } \\
\left(\mathrm{L}_{\mathrm{AB}}\right)\end{array}$ & $\begin{array}{l}\text { Average daily run rate } \\
\qquad\left(\mathrm{V}_{\mathrm{N}}\right)\end{array}$ & Transportation time \\
\hline & & km & km/day & day \\
\hline \multirow[t]{3}{*}{1} & Total & 10,634 & - & 9.8 \\
\hline & TKR & 1,300 & 650 & 2.0 \\
\hline & TSR & 9,334 & 1,200 & 7.8 \\
\hline \multirow[t]{4}{*}{2} & Total & 9,192 & - & 10.8 \\
\hline & TKR & 945 & 650 & 1.5 \\
\hline & TMR & 1,694 & 439 & 3.9 \\
\hline & TSR & 6,553 & 1200 & 5.5 \\
\hline \multirow[t]{5}{*}{3} & Total & 9,704 & - & 12.6 \\
\hline & TKR & 945 & 650 & 1.5 \\
\hline & TCR & 1,854 & 439 & 4.2 \\
\hline & TMGR & 1,110 & 532 & 2.1 \\
\hline & TSR & 5,795 & 1,200 & 4.8 \\
\hline \multirow[t]{5}{*}{4} & Total & 10,680 & & 19.2 \\
\hline & TKR & 945 & 650 & 1.5 \\
\hline & TCR & 5,596 & 439 & 12.7 \\
\hline & TKZR & 1,910 & 600 & 3.2 \\
\hline & TSR & 2,229 & 1,200 & 1.9 \\
\hline
\end{tabular}

Source: TKR: Trans-Korean Railways

TSR: Trans-Siberian Railways: http://www.rzd.ru

TCR: Trans-Chinese Railways: http://www.chineserailways.com/us/HR.html

TMR: Trans-Manchurian Railways: same as TCR

TMGR: Trans-Mongolian Railway Company: http://www.mtz.mn

TKZR: Trans-Kazakhstan Railways: http://www.railways.kz

\section{(2) Customs Procedures and Cross-border Factors}

The second term of the right-hand side of (Eq.1), $\varepsilon$, represents time for additional procedures occurring during the process of cargo transportation. The efficiency of customs procedures and cross-border factors belong to $\varepsilon$. Effective customs clearance procedures and a simple border crossing mechanism directly and positively affect the efficiency of railways.

The two main types of delays which can interfere with the smooth flow of border crossing railway traffic are: (1) Delays due to customs and security control procedures; and (2) Delays due to railway operational procedures, such as train inspections, brake testing, checking of wagons and their equipment, recording of wagon and consignment details, etc. 
Relying on previous studies, such as Balalaev, et al. (2009), Rosbalt (2009), and Zhalairov (2009), this paper utilizes the finding that it takes an average of about 3 hours for the official customs procedures and railway operational procedures at each 'normal' border-crossing point. However, the border-crossing in Kazakhstan is known to be very inefficient; it takes about twice the normal time The border-crossings in North Korea (DPRK) and Russia, on the other hand, known to be very efficient because they have been used for longer periods of time, and the customs and operation systems of the two countries are more or less harmonized. As a result, it takes only half the time for trains to cross their borders than at other crossing points.

Comparison of the four alternative routes in terms of time consumed on the border-crossing points is shown in Table 3. The most time-consuming cross-border procedures are experienced along Route 4. because of the larger number of border-crossing points along the route and the low efficiency of the China-Kazakhstan and the Kazakhstan-Russia borders which make up more than $60 \%$ of the total time required to complete this route. Route 3 requires 6 hours less than Route 4, despite the same number of border-crossings. Route 1 requires the least time because it has the fewest border-crossing points and enjoys relatively efficient customs procedures between North Korea and Russia, thereby displaying its high competitiveness among the four alternative routes.

Table 3.

Time Consumption at Border-crossing Points

(Unit: hour)

\begin{tabular}{|c|c|c|c|c|}
\hline & \multicolumn{4}{|c|}{ Border-crossing points on Route } \\
\hline & 1 & 2 & 3 & 4 \\
\hline \multirow{4}{*}{$\begin{array}{l}\text { Time for } \\
\text { border } \\
\text {-crossing } \\
\text { procedures }\end{array}$} & ${ }^{\mathrm{ROK} / \mathrm{DPRK}}$ & ${ }_{3}^{R O K / D P R K}$ & ${ }_{3}^{\text {ROK/DPRK }}$ & ${ }_{3}^{\text {ROK/DPRK }}$ \\
\hline & $\begin{array}{l}\text { DPRK/Russia } \\
1.5\end{array}$ & $\begin{array}{r}\text { DPRK/China } \\
3\end{array}$ & $\begin{array}{r}\text { DPRK/China } \\
\end{array}$ & $\begin{array}{l}\text { DPRK/China } \\
3\end{array}$ \\
\hline & & China/Russia & $\begin{array}{r}\text { China/Mongolia } \\
3\end{array}$ & $\begin{array}{r}\text { China/Kazakhstan } \\
6\end{array}$ \\
\hline & & & $\begin{array}{r}\text { Mongolia/Russia } \\
3\end{array}$ & $\begin{array}{r}\text { Kazakhstan/Russia } \\
6\end{array}$ \\
\hline Total & 4.5 & 9 & 12 & 18 \\
\hline
\end{tabular}

Note: Scale for efficiency of border-crossing procedures: $\square$-inefficient; $\square$-satisfactory; $\square$-efficient.

Source: Balalaev et. al.(2009); Rosbalt (2009); Zhalairov (2009); CCTT, Russian Railways; NELTY; Wikipedia 
Apart from delays caused by inefficiencies in customs procedures and railway operational procedures, this paper pays special attention to the likelihood of corruption. The 'corruption' at the border points seriously interferes with the smooth flow of border-crossing railway traffic. Corruption is known to be a serious obstacle to the transparent and speedy border-crossing in many countries.

The level of corruption could be a helpful indicator of the degree of transparency and efficiency of the national customs procedures. The higher its value, the more the likelihood of cumbersome, time-consuming and expensive border-crossing procedures. with this in mind, this study uses observations of The Heritage Foundation on "The Freedom for Corruption Index."

According to The Heritage Foundation (2009), the indexes of the freedom from corruption for countries are classified into four categories: 1-moderate; 2-high; 3-very high; 4-extremely high. Among the five countries on the route, the Republic of Korea has the lowest level of corruption and therefore belongs in the first category. North Korea, on the contrary, has the highest level of corruption and is in the forth category. Russia and Kazakhstan are found to have approximately the same level and classified in the third group. In these countries corruption is perceived as pervasive, indicating the presence of a serious problem. China and Mongolia are grouped into the second group due to their similar values of the index. The corruption in China and Mongolia is perceived as widespread.

Utilizing the freedom from corruption index, the result of the grouping and scoring is shown in Table 4. The numbers (North Korea $=4$, Russia and Kazakhstan $=3$, China and Mongolia =2, South Korea =1) are used as a proxy indicating the index for corruption level of the country's border points.

Table 4.

Application of the corruption level to the route efficiency.

\begin{tabular}{|c|c|c|c|c|c|c|c|}
\hline \multirow{3}{*}{ Route } & \multicolumn{6}{|c|}{ Countries along the route/score } & \multirow[t]{3}{*}{ Score } \\
\hline & ROK & DPRK & Russia & China & Mongolia & Kavakhstan & \\
\hline & 1 & 4 & 3 & 2 & 2 & 3 & \\
\hline 1 & & & & & & & 8 \\
\hline 2 & & & & & & & 10 \\
\hline 3 & & & & & & & 12 \\
\hline 4 & & & & & & & 13 \\
\hline
\end{tabular}

Note: Level of corruption: $\square$ moderate; high; $\square$ very high; $\square$ extremely high.

Scale: from 1 to 4 (4-the most serious) 
We assume the result of Route 1 (score=8) as the basis and equals ' 1 day delay' on the border crossing point. Therefore, interpreting scores for Routes 2, 3 and 4 into days with respect to Route 1 we get $1.25,1.5$ and 1.63 days respectively. The final results for the border crossing factor can be found in Table 5 below.

Table 5.

The efficiency of border-crossing

(Unit: hour)

\begin{tabular}{c|c|c|c}
\hline \multirow{2}{*}{ Route } & \multicolumn{2}{|c|}{ Components } & \multirow{2}{*}{ Total } \\
\cline { 2 - 4 } & Customs procedures & Level of comuption & \\
\hline \hline 1 & 0.19 & 1.00 & $\mathbf{1 . 1 9}$ \\
\hline 2 & 0.38 & 1.25 & $\mathbf{1 . 6 3}$ \\
\hline 3 & 0.50 & 1.50 & $\mathbf{2 . 0 0}$ \\
\hline 4 & 0.75 & 1.63 & $\mathbf{2 . 3 8}$ \\
\hline
\end{tabular}

In sum, Route 1 is the most competitive among the four alternative routes in terms of time consumption on the border-crossing procedures and the seriousness of corruption that might influence the effectiveness of the railway routes. Route 2 and Route 3 are second and third respectively in border-crossing efficiency. The least appropriate route in terms of these two aspects is Route 4.

\section{(3) Gauge Difference}

The track gauge is the distance between the inner surface of each rail usually measured in millimeters. A break-of-gauge occurs when the railways of neighboring countries have different track gauges. The consequence is that rolling-stock cannot be exchanged across borders, thereby calling for measures to transfer people and cargo. As a result, the gauge difference belongs to $\varepsilon$ in (Eq.1) resulting in additional time for cargo transportation.

The problem of gauge difference arises when railways are connected internationally. Additional time spent at the break-of-gauge point for transshipment of cargo requires necessary facilities and reliable technology to solve the gauge difference problem. Transshipment methods that are currently being used to overcome the gauge difference between railways are time-consuming and costly in most cases. 
There are two types of rail gauges in the region: standard gauge $(1,435 \mathrm{~mm})$ used by North Korea, South Korea, China and most European countries and a broad gauge rails $(1,520 \mathrm{~mm})$ used by Russia, Mongolia, and Kazakhstan. Therefore each of the four routes requires only one transshipment at the break-of-gauge point as shown in Table 6. An adjustment at the break-of-gauge point for transshipment generally takes about 3 hours. In sum, all routes consume 0.125 days because of one time gauge difference along the connected railways from Busan to Moscow.

\section{Table 6.}

The Gauge Difference

\begin{tabular}{c|l|l}
\hline Route & \multicolumn{1}{|c|}{ Gauge difference } & \multicolumn{1}{c}{ Break-of-gauge point } \\
\hline \hline 1 & $\begin{array}{l}\text { Korean standard gauge }(1.435 \mathrm{~mm}) \\
\text { Russian broad gauge }(1.520 \mathrm{~mm})\end{array}$ & Tumangang (DPRK) / Khasan (Russia) \\
\hline 2 & $\begin{array}{l}\text { Korean standard gauge }(1.435 \mathrm{~mm}) \\
\text { Russian broad gauge }(1.520 \mathrm{~mm})\end{array}$ & Manzhouli (China) / Zabaikalks (Russia) \\
\hline 3 & $\begin{array}{l}\text { Korean standard gauge }(1.435 \mathrm{~mm}) \\
\text { Russian broad gauge }(1.520 \mathrm{~mm})\end{array}$ & Erenhot (China) / Zamyn-Uud (Mongolia) \\
\hline 4 & $\begin{array}{l}\text { Korean standard gauge }(1.435 \mathrm{~mm}) \\
\text { Russian broad gauge }(1.520 \mathrm{~mm})\end{array}$ & Alashankou (China) / Druzhba (Kazakhstan) \\
\hline
\end{tabular}

Source: $\mathrm{Na}(2004)$.

However, the break-of-gauge does not constitute a major problem to the efficiency of railways. Break-of-gauges mostly occur at border points where a range of other operations already require trains to stop. Nonetheless many researchers address the problem by offering an alternative to transshipment or bogie-changing: the variable-gauge systems.

\subsection{Benefit Factors}

The benefit side of a connected railway can be most easily perceived by the total size of cargo from Busan, South Korea to Europe. As we have seen in Section 2, this paper selects four main beneficial factors of connected railways: (1) volume of cargo; (2) industrial production of adjacent regions; (3) access to natural resources; and (4) market size and investment climate. 
One of the most distinguishing features of this study, applied in this subsection, is that we estimate all four types of cargo by adjacent regions as opposed to national level. Most literature uses national data in conjecturing the size of consignments, but it overestimates cargo size. In particular, the railways running through big countries like Russia, China and Kazakhstan have quite different implications for the size of cargo. If the railway goes through an industrial region, mining or agricultural area, or big-market region, it could load and unload much larger cargo than otherwise. Thus the use of adjacent regions is of critical importance, particularly when the four connected railways run through different regions of China and Russia.

\section{(1) Volume of Cargo}

The volume of bilateral exports for each country is used for cargo estimation. Each route goes through several countries on its way, thus it is possible to distinguish several pairs of trade partners and calculate their total trade volumes. The calculation is based on the trade statistics of 2007 and the results are presented in Table 7.

Table 7.

The volume of national cargo along the four alternative routes.

(Unit: US\$ billion)

\begin{tabular}{c|c}
\hline Route & Volume of Cargo \\
\hline \hline 1 & 423.5 \\
\hline 2 & $1,022.9$ \\
\hline 3 & $1,026.2$ \\
\hline 4 & $1,079.6$ \\
\hline
\end{tabular}

Source: UN Comtrade Database 2007.

However, export values of countries in the table are exaggerated for the estimation of cargo volume, because it used country-level data. Which cannot be used. The provinces or states are different within a country along the alternative routes. Therefore there is a need for adjustment for more accurate estimates of cargo volumes along the four routes.

The share of Gross Regional Domestic Product (GRDP) of adjacent regions along each railway route to the GDP of a country is used as a tool for adjustment of cargo volume. 5 For example, the total size of cargo of Route 4 is estimated by the sum of $100 \%$ 
of South Korea's GDP, 100\% of North Korea's GDP, 33.1\% of Russia's GDP, 23.8\% of China's GDP, and $47 \%$ of Kazakhstan's GDP, as seen in the 4th row of the table. As such, the share of regional GRDP to national GDP for each route is shown in Table 8 below. 6

Table 8.

The ratio of GRDP of adjacent regions to the national GDP of each route

(Unit: \%)

\begin{tabular}{c|c|c|c|c|c|c}
\hline \multirow{2}{*}{ Route } & \multicolumn{5}{|c}{ Country } \\
\cline { 2 - 7 } & ROK & DPRK & Russia & China & Mongolia & Kazakhstan \\
\hline \hline $\mathbf{1}$ & 100 & 100 & 54.0 & & & \\
\hline $\mathbf{2}$ & 100 & 100 & 52.1 & 7.2 & & \\
\hline $\mathbf{3}$ & 100 & 100 & 51.7 & 16.5 & 100 & \\
\hline $\mathbf{4}$ & 100 & 100 & 33.1 & 23.8 & & 47.0 \\
\hline
\end{tabular}

Source: China Statistical Yearbook, Federal State Statistics Service of Russian Federation,

The Agency of Statistics of the Republic of Kazakhstan

In addition, the pace of economic growth varies from country to country along the routes. In order to estimate prospective volumes of cargo accumulated on each of the four alternative routes, we need to incorporate the difference in the economic growth rates of each country. The application of the differential growth rate of the countries will correct any distortion that could result from oversimplifying the performance of the countries. The annual GDP growth rates of 2008 are used to incorporate the differences in the regional economic growth rates.

In sum, the total volume of cargo for each route is corrected by (1) using adjacent regions rather than countries as shown in Table 8, and (2) using the differential regional economic growth rates of 2008 is presented in Table 9.

\footnotetext{
5 See Table A1 in Appendix for the detailed list of the provinces or states that are used for adjacent regions.

6 In actual calculation we omit the cargo volumes of North and South Korea in comparing the efficiency of routes. As this size of cargo volume enters all the four routes it can be omitted for the sake of simplicity.
} 
Table 9.

The volume of cargo by routes

(Unit:US\$ billion)

\begin{tabular}{c|c}
\hline Route & Volume of Cargo \\
\hline \hline Route 1 & 338.73 \\
\hline Route 2 & 584.40 \\
\hline Route 3 & 607.01 \\
\hline Route 4 & 619.02 \\
\hline
\end{tabular}

Source: UN Comtrade Database, 2008

According to the estimation result, Route 4 maintains its superiority in terms of cargo volume. The second cargo size belongs to Route 3, followed by Route 2, then by Route 1 .

\section{(2) Industrial production of adjacent regions}

This factor was first inspired by the works of Uyanaev (2008). Uyanaev mentioned that "transcontinental freight routes open up additional possibilities for the development of economic cooperation between countries, facilitate the development of areas adjacent to tr ansportation lines, and represent good potential for the development of transportation and economic infrastructure in the region." Therefore it might be expected that these processes will contribute to the revitalization and intensification of industrial development in the region as well, followed by increased production. The increased production, in turn, would result in additional cargo volume generated along the route.

However, the level of industrial development varies from region to region and should be taken into consideration, when estimating prospective cargo volume of the four alternative routes.

Abramov, et al. (2002) introduced the concept of industrial transit. The characteristic of this type of transit is a creation of facilities along communications for the processing of goods. Industrial transit can be an essential factor for the expansion and creation of production plants, not exclusively for mining, but for the manufacturing industry as well. Thus the availability of industrial facilities in the regions crossed by the flow of cargo can be considered as a competitive advantage of a transportation route.

As such this paper incorporates the 'industrial production of adjacent regions' as one of the important categories of the benefit-side factors . Industrial output is used as a proxy for the estimates of industrial production. The data are collected for the adjacent regions to each of the four alternative routes. Table 10 presents the results. 
Table 10.

Industrial production of the adjacent regions by routes

(Unit: US\$ billion)

\begin{tabular}{c|c|c|c|c|c}
\hline \multirow{2}{*}{ Route } & \multicolumn{5}{|c}{ Industrial output } \\
\cline { 2 - 6 } & Russia & China & Mongolia & Kazakhstan & Total \\
\hline \hline $\mathbf{1}$ & 611.5 & & & & 611.5 \\
\hline $\mathbf{2}$ & 604.4 & 145.4 & & & 749.8 \\
\hline $\mathbf{3}$ & 603.3 & 392.8 & 1.9 & 12.6 & 997.9 \\
\hline $\mathbf{4}$ & 462.1 & 490.0 & & & 964.8 \\
\hline
\end{tabular}

Source: Mongolian Statistical Yearbook 2008, Federal State Statistics Service of Russian

Federation, the Agency of Statistics of the Republic of Kazakhstan,

Chinese Statistical Yearbook 2008, Hong Kong Trade Development Council.

It is worthwhile noting that the size of industrial production is not the size of cargo by itself. Cargo comes as a result of industrial activities and the intensity of activities is implied in the industrial production. Thus we have to develop a way to derive the expected size of cargo from the industrial production.

In order to determine the size of cargo from the industrial production, this paper suggests following line of logic: The ratio of exports to GDP can be used in estimating the size of cargo from GDP. It means that the size of cargo is nothing but the volume of exports of the adjacent regions. However, GDP and industrial production are different from each other. While GDP is measured in terms of value-added, industrial production counts multiple of those value-added. We utilize the interest rate to curb the multiple-counting problem. ${ }^{7}$ The correction coefficient for industrial output, Ic, can be estimated by the following formula:

[Volume of Cargo] $=[$ Industrial Production $] *$ [Correction coefficient (Ic)]

$\mathrm{Ic}_{\mathrm{i}}=\left(\right.$ Export $\left._{\mathrm{i}} / \mathrm{GDP}_{\mathrm{i}}\right) *$ Interest rate $\mathrm{i}_{\mathrm{i}}$

where, $\mathrm{i}=$ country $\mathrm{i}$ on the route.

Table 11 shows the mechanism of the correction coefficient calculation for the countries on the route based on 2007 data. Table 12 presents the volume of cargo that is derived from industrial production.

\footnotetext{
7 The correct one will be a value-added ratio. However this ratio depends not only on labor input, capital input, and material input, but on composition of industries as well. Thus it is too complex to estimate. To avoid the complication, we assume there is only capital input. Differing from labor input, capital remains identical across industries and across regions thereby enabling a consistent comparison among the four alternative railway routes. Under the assumption of capital input and normal profit, interest rates are just the cost of capital. They are the only element of value-added. While this calculation may understate the size of cargo for each route, it could provide the cargo difference between different routes that matches the objective of this paper.
} 
Table 11.

Correction coefficient for industrial output.

\begin{tabular}{c|c|c|c|c}
\hline Country & $\begin{array}{c}\text { Export } \\
\text { (US\$ billion) }\end{array}$ & $\begin{array}{c}\text { GDP } \\
\text { (US\$ billion) }\end{array}$ & $\begin{array}{c}\text { Interest rate } \\
\text { (\%) }\end{array}$ & Ic \\
\hline \hline China & $1,217.78$ & $3,250.83$ & 3.33 & 1.25 \\
\hline Kazakhstan & 47.80 & 103.84 & 11.00 & 5.06 \\
\hline Mongolia & 1.89 & 3.91 & 9.87 & 4.77 \\
\hline Russia & 352.27 & $1,289.58$ & 10.00 & 2.73 \\
\hline
\end{tabular}

Source: UN Comtrade Database, IMF, CIA World Factbook.

Table 12.

Industrial output adjusted by correction coefficient (Ic).

(Unit: US\$ billion)

\begin{tabular}{c|c|c|c|c|c}
\hline \multirow{2}{*}{ Route } & \multicolumn{5}{|c}{ Industrial output } \\
\cline { 2 - 6 } & Russia & China & Mongolia & Kazakhstan & Total \\
\hline \hline $\mathbf{1}$ & 16.70 & & & & 16.70 \\
\hline $\mathbf{2}$ & 16.52 & 1.81 & & & 18.32 \\
\hline $\mathbf{3}$ & 16.48 & 4.90 & 0.89 & & 21.47 \\
\hline $\mathbf{4}$ & 12.62 & 6.11 & & 0.64 & 19.37 \\
\hline
\end{tabular}

Source: Same as in Table 10.

The result shows that Route 3 is the most competitive route in terms of industrial production of adjacent regions. Route 4, Route 2 and Route 1 follow in that order.

\section{(3) Access to natural resources}

Lee J.Y. (2004), Park (2006), Brooks (2008) and Balalaev, et al. (2008) addressed the importance of natural resources from which additional volume of cargo can be generated.

In particular, Park (2006) considered the abundance of natural resources of the Russian Far East and perspective routes for its mining production transporting to neighboring countries. The Russian economy is export-oriented and natural resources are a major part of its exports. Thus, over the last three years, crude oil, non-crude oil, petroleum gas, iron ore 
and coal have been among the top ten export commodities. As such the access to natural resources is an important benefit factor in connecting the railways.

The trans-Siberian railway passes through the territories of 20 subjects of the Russian Federation and 5 federal districts. These regions, rich with natural resources, have significant export and import potential. In the regions the trans-Siberian railway serves, about $65 \%$ of coal, $20 \%$ of oil refining and $25 \%$ of release of business wood . According to Balalaev, et al. (2008), more than $80 \%$ of industrial potential of the country and the basic natural resources are concentrated in this region, including oil, gas, coal, wood, ores, ferrous and non-ferrous metals, and so on.

Crude materials account for a significant portion of Mongolian exports as well. From 2005 to 2007, the three major exported products were copper ore and concentrates, gold, (including gold plated with platinum), and zinc ore and concentrates. From 2003 to 2007, exports of crude materials (excluding fuels), oils, and fats increased fivefold and accounted for $71 \%$ of total exports in 2007.

Crude petroleum oil, the top export commodity, accounted for $61.1 \%$ of Kazakh exports in 2008. China also has large exports of natural resources.

Usually the output of a nation's mining industry comprises a major portion of natural resources. Thus the mining sector can be taken as a proxy for estimating the extent of the access to natural resources. Table 13 presents mining industry output of adjacent regions along the four railway routes.

Table 13.

Mining industry output by route.

(Unit: US\$ billion)

\begin{tabular}{c|c|c|c|c|c}
\hline \multirow{2}{*}{ Route } & \multicolumn{5}{|c}{ Mining industry output } \\
\cline { 2 - 6 } & Russia & China & Mongolia & Kazakhstan & Total \\
\hline \hline $\mathbf{1}$ & 94.38 & & & & 94.38 \\
\hline $\mathbf{2}$ & 93.56 & 40.65 & & & 134.20 \\
\hline $\mathbf{3}$ & 93.10 & 57.37 & 1.22 & & 151.69 \\
\hline $\mathbf{4}$ & 19.76 & 100.26 & & 1.13 & 121.15 \\
\hline
\end{tabular}

Source: Same as in Table 10.

The results clearly shows Route 3's high competitiveness in terms of access to natural resources, accumulating the highest mining industry output on the route. As trade in crude materials accounts for the majority of Russian and Mongolian exports in particular, the high mining industry output is expected to contribute to higher cargo traffic along the route.

The lowest value belongs to Route 1, as the countries with significant reserves of natural resources, such as China and Mongolia are excluded from the route. Route 4 is less competitive in terms of access to natural resources because it comprises only a small part of Russia with the territories most abundant with natural resources being left out. 
However, the volume of mining industry output will not contribute to cargo volume in full. A portion of mining industry production will be consumed locally. However, the rest of the output will be put on exports. In order to calculate the share of mining industry output, that will contribute to the growth of cargo volumes along the route, we will apply correction coefficient, Mc, which can be estimated by the formula:

$\mathrm{Mc}=$ Export of mining products $\mathrm{i} /$ Output of mining industry $\mathrm{i}_{\mathrm{i}}$

where, $i$ denotes country $i$

Table 14 shows the derivation of the correction coefficient, Mc. Finally Table 15 presents the volume of cargo along the four routes. The table shows that Route 3 maintains the most favorable position in terms of access to natural resources.

Table 14.

Correction Coefficient for Mining Industry Output.

\begin{tabular}{c|c|c|c}
\hline Country & $\begin{array}{c}\text { Export of mining } \\
\text { (US\$ billion) }\end{array}$ & $\begin{array}{c}\text { Output of mining } \\
\text { (US\$ billion) }\end{array}$ & Mc (\%) \\
\hline \hline China & 46.28 & 1594.86 & 2.90 \\
\hline Kazakhstan & 33.00 & 35.60 & 92.70 \\
\hline Mongolia & 1.10 & 1.23 & 89.43 \\
\hline Russia & 257.31 & 425.56 & 60.46 \\
\hline
\end{tabular}

Source: UNCTAD Handbook of Statistics 2008, WTO Statistics, ERINA Country Data

Table 15.

Mining Industry Output Adjusted by Correction Coefficient.

(Unit: US\$ billion)

\begin{tabular}{c|c|c|c|c|c}
\hline \multirow{2}{*}{ Route } & \multicolumn{5}{|c}{ Mining industry output } \\
\cline { 2 - 6 } & Russia & China & Mongolia & Kazakhstan & Total \\
\hline \hline $\mathbf{1}$ & 57.07 & & & & 57.07 \\
\hline $\mathbf{2}$ & 56.57 & 1.18 & & & 57.75 \\
\hline $\mathbf{3}$ & 93.10 & 1.66 & 1.09 & & 95.86 \\
\hline $\mathbf{4}$ & 11.95 & 2.91 & & 1.04 & 15.90 \\
\hline
\end{tabular}

Source: Same as in Table 10.

\section{(4) Market size and investment climate}

Brooks (2008) found that the way in which road/rail infrastructure affects trade, whether domestic or cross border, operates mainly through reductions in transportation 
costs. The reductions in transportation costs have positive impact on foreign direct investment (FDI) inflows by reducing transaction costs in intra-firm vertical integration that is designed to exploit countries' comparative cost advantages. Increases in FDI, in turn, further enhances regional trade, and add to the direct effect of reduced transportation costs achieved through improvements in road/railway infrastructure near border areas. When such gains are present, this reduces tendencies towards production agglomeration. If the advantages of production integration across economies outweigh those from agglomeration, then reductions in transportation costs make FDI complementary to trade. This defines a virtuous cycle of cross-border infrastructure development, trade, and investment that fosters increased trade and economic growth.

Nekhoroshkov (2009) observes that foreign direct investment is an important catalyst of regional trade growth and therefore is expected to have a positive impact on cargo traffic between regions within a country and internationally. Thus foreign capital inflows into a region will result in additional cargo volume. For this reason this paper selects market size and investment climate as important benefit factors.

FDI inflow will contribute to additional industrial output, which in turn, will raise export volumes therefore contributing to the increasing cargo volumes generated along the four alternative routes. However, there is a need for adjustment on the value of FDI. The question is to find out the value of the correcting coefficient for the foreign direct investment, FDIc.

In this paper, we assume the value of FDIc remains at 5\%. This number was drawn from Table 11 where the correcting coefficient for industrial production, Ic, has a value lying between $1.25 \sim 5.06 \%$. We assume that FDI will contribute to the export volume in proportion of $5 \%$ of the total amount of FDI accumulated at the regions on the route. The result of the FDI adjustment is presented in Table 16.

Table 16.

Foreign Direct Investment Inflow adjusted by correction coefficient .

(Unit: US\$ billion)

\begin{tabular}{c|c|c|c|c|c|c|c}
\hline \multirow{2}{*}{ Route } & \multicolumn{5}{|c|}{ FDI } & FDIc & $\begin{array}{c}\text { FDI-adjusted } \\
\text { cargo volume }\end{array}$ \\
\cline { 2 - 8 } & Russia & China & Mongolia & Kazakhastan & Total & & \\
\hline \hline $\mathbf{1}$ & 86.05 & & & & 86.05 & 5 & 4.30 \\
\hline $\mathbf{2}$ & 85.77 & 12.07 & & & 97.84 & 5 & 4.89 \\
\hline $\mathbf{3}$ & 85.69 & 22.64 & 0.05 & & 108.83 & 5 & 5.44 \\
\hline $\mathbf{4}$ & 72.67 & 26.32 & & 0.14 & 99.13 & 5 & 4.96 \\
\hline
\end{tabular}

Source: Same as in Table 10. 


\section{Selection of the Best Route}

In the previous Section, the researchers have estimated all the costs and benefits in connecting the railways. Thus we are now at the position in which we can select the best route among the four different connections of the trans-Korean and trans-Siberian railways.

The selection can be done in a simple analytical framework of cost and benefit comparison. The comparison is carried out by calculating the difference between cost and benefit measured by [benefit minus cost] - along each route. The greater the value of the net benefit of a route, the more efficient the route is.

Table 17 presents all the costs of each route. Row 1.1 comes from Table 2 of the previous Section; as such, row 1.2 and 1.3 from Table 5; row 1.4 from table 6. The last column SUM 1 shows the total delivery time of each route. For example, Route 4 requires 21.6 days to transport consignments from Busan to Moscow.

Similarly Table 18 presents the benefits in terms of total size of cargo of each route. For instance, we expect about 639.36 billion US Dollars' worth cargo volume when transportation is done along Route 2. The total size of cargo is greatest on Route 3, followed by Route 4 the Route 2 , whereas it is smallest on Route 1.

The row 2.1, 2.2, 2.3, and 2.4 are duplications of the previous tables, Table 9, Table 12, Table 15, and Table 16, respectively.

Table 17.

Cost-benefit Analysis: Cost Side.

(Unit: day)

\begin{tabular}{c|c|c|c|c|c}
\hline $\mathbf{1}$ & Determining factor & Route 1 & Route 2 & Route 3 & Route 4 \\
\hline \hline $\mathbf{1 . 1}$ & Transportation time & 9.8 & 10.8 & 12.6 & 19.2 \\
\hline $\mathbf{1 . 2}$ & $\begin{array}{c}\text { Effectiveness of customs procedures } \\
\text { and cross- border factor }\end{array}$ & 0.19 & 0.38 & 0.50 & 0.75 \\
\hline $\mathbf{1 . 3}$ & $\begin{array}{c}\text { Seriousness of the problem of } \\
\text { corruption }\end{array}$ & 1.0 & 1.25 & 1.5 & 1.625 \\
\hline $\mathbf{1 . 4}$ & $\begin{array}{c}\text { Gauge difference } \\
\text { Total Delivery Time (SUM 1) }\end{array}$ & $\mathbf{1 1 . 0}$ & $\mathbf{1 2 . 4}$ & $\mathbf{1 4 . 6}$ & $\mathbf{2 1 . 6}$ \\
\hline
\end{tabular}

Note: Gauge difference was not included in SUM 1 as it has the same value for all four routes. 
Table 18.

Cost-benefit Analysis: Cost Side.

(Unit: US\$ billion)

\begin{tabular}{c|c|c|c|c|c}
\hline $\mathbf{2}$ & Determining factor & Route 1 & Route 2 & Route 3 & Route 4 \\
\hline \hline $\mathbf{2 . 1}$ & $\begin{array}{c}\text { Cargo corrected on the Economic } \\
\text { growth of countries }\end{array}$ & 338.73 & 558.40 & 607.01 & 619.02 \\
\hline $\mathbf{2 . 2}$ & $\begin{array}{c}\text { Industrial production of adjacent } \\
\text { regions }\end{array}$ & 16.70 & 18.32 & 21.47 & 19.37 \\
\hline $\mathbf{2 . 3}$ & $\begin{array}{c}\text { Access to natural resources in } \\
\text { adjacent regions }\end{array}$ & 57.07 & 57.75 & 95.86 & 15.90 \\
\hline $\mathbf{2 . 4}$ & $\begin{array}{c}\text { Market size and investment climate } \\
\text { of adjacent regions }\end{array}$ & 4.30 & 4.89 & 5.44 & 4.96 \\
\hline & $\begin{array}{c}\text { Total Size of Cargo } \\
\text { (SUM 2) }\end{array}$ & $\mathbf{4 1 6 . 8 0}$ & $\mathbf{6 3 9 . 3 6}$ & $\mathbf{7 2 9 . 7 8}$ & $\mathbf{6 5 9 . 2 5}$ \\
\hline
\end{tabular}

However, there is a serious problem for a cost-benefit comparison. The costs are expressed in terms of days and hours, but the benefits are in US Dollars: One is a physical time, whereas the other is in monetary value. How can we reconcile the unit differences in order to perform a reasonable comparison of cost and benefit for each route? Certainly this is not an easy question. It is precisely the reason why there has not been any research comparing routes or determining the most efficient route.

In order to overcome the different unit problem, this paper aims to utilize the empirical results of preceding research.

Hausman et al (2005) and Djankov et al (2005) presented the important finding that a $10 \%$ increase in transportation time reduces bilateral trade volume by 5 to $8 \%$. Huziyatov (2008) notes that the increase of transportation time by 1 day reduces its exports by $1.5 \%$.

In this paper we accept the relationship between the physical time and monetary value such that every $10 \%$ increase in transportation time reduces the volume of bilateral trade by 5\% following the results of Hausman and Djankov. The finding of Huziyatov such that the increase of transportation time by 1 day reduces the likelihood of its exports by $1.5 \%$ is almost identical to the findings of Hausman and Djankov. Considering that usually 30 35 days are needed to transport cargo via all-water-routes from East Asian countries to Europe, 1 day is a $3 \%$ of total delivery time: It means that about 3\% increase in transportation time reduces exports by $1.5 \%$; exactly the same as determined in the two previous studies.

In applying the above principle, we first make the indexes for the costs taking Route 1 as the basis (100\%). The cost index for each route is shown in Table 19. Then we introduce the transformation coefficient: the coefficient that translates physical time into monetary value. 
As the Route 1 was taken as the basis for the cost index, the value of the transformation coefficient of Route 1 equals zero. For Route 2, a 13\% increase of the cost will reduce the benefit by $6.5 \%$; 33\% increase of the cost will reduce the benefit of Route 3 by $16.5 \%$ and $96 \%$ increase of the cost will reduce the benefit of the Route 4 by $48 \%$.

Finally the benefit- cost comparison can be performed by the following formula:

$(\mathrm{B}-\mathrm{C})=\mathrm{B}^{*}(1-\mathrm{Tc})$ (Eq. 4)

where, $\mathrm{B}=$ benefit; $\mathrm{C}=$ cost; $\mathrm{Tc}=$ transformation coefficient.

Table 19.

Results of the Cost-Benefit Analysis.

\begin{tabular}{c|c|c|c|c|c|c}
\hline \multicolumn{2}{c|}{} & Unit & Route 1 & Route 2 & Route 3 & Route 4 \\
\hline \hline \multirow{2}{*}{ Cost } & SUM 1 & day & 11.0 & 12.4 & 14.6 & 21.6 \\
\hline & Cost Index & $\%$ & 100 & 113 & 133 & 196 \\
\cline { 2 - 7 } & $\begin{array}{c}\text { Transformation } \\
\text { coefficient }\end{array}$ & $\%$ & 0.0 & 6.5 & 16.5 & 48.0 \\
\hline \multirow{2}{*}{ Benefits } & SUM 1 & $\begin{array}{c}\text { US\$ } \\
\text { billion }\end{array}$ & 416.80 & 639.36 & 729.78 & 659.25 \\
\hline \multicolumn{2}{c|}{ Benefit-Cost result } & $\begin{array}{c}\text { US\$ } \\
\text { billion }\end{array}$ & $\mathbf{4 1 6 . 8 0}$ & $\mathbf{5 9 7 . 8 0}$ & $\mathbf{6 0 9 . 3 7}$ & $\mathbf{3 4 2 . 8 1}$ \\
\hline
\end{tabular}

In order to determine the most economically efficient transportation route, we need to find the maximum value of the Benefit-Cost difference: Max (B-C). According to the estimation, Route 3 is the most efficient railway route among the four alternative railways. Route 2 is the second. In comparison to Routes 3 and 2, Routes 1 and 4 are less favorable.

\section{Conclusion}

The objective of this study was simple and straightforward: It was to find out the most efficient route among the four alternative routes connecting the trans-Korean and trans-Siberian railways. The conclusion is also straightforward: Route 3 is the most efficient. Route 3 goes through Busan - Seoul (South Korea) - Pyongyang - Sinuiju (North Korea) - Shenyang - Beijing - Erenhot (China) - Ulaanbaatar (Mongolia) - Ulan-Ude Moscow (Russia). 
In doing so, this study attempts to develop an economic analytical framework in which different railway routes can be evaluated on both cost and benefit fronts. For the first time, several new equations in estimating the costs and benefits involved in each route are laid out. Some new concepts of costs and benefits are also introduced. In particular this paper also provides a way to overcome the difference in units between costs and benefits. It is a brave attempt and may call for further studies. It was possible as this paper had an extensive review of related literatures that used to be scattered about.

This research is the first attempt to provide a system of determining factors for the route selection: On the costs front, transportation time, effectiveness of customs procedures and cross-border factors, problems of corruption, and gauge differences were included. On the benefits front, this paper encompasses volume of cargo considering adjacent region issues and differential growth rates of the regions, industrial production in adjacent regions, access to natural resources in adjacent regions, market size and investment climate. All of these concepts are accompanied by actual measurements.

\section{References}

Abramov et al.(2002) "Non-transport effect of the railroads operation". Railroad Transport. No 3. pp.58-62.

Ahn B.M. (2002) "Restoration of the Seoul-Shinuiju Line: Review and Outlook", East Asian Review, 14, 1, pp.107-119.

Anikin B.A. (2002). "Praktikum po logistike" ("Logistics workshop"), INFRA-M, p.273-275. Asan Zhalairov, Jungarskie vorota v Europu. 21.04.2009. Gudok. Available at: http://www.gudok.ru/newspaper/detail.php?ID=311911\&SECTION ID $=15103$ \&year $=2009 \&$ month $=04$

Balalaev A.S., Dynkin B.E., Tretiyak S.N. (2008) "Modern Opportunities and Prospects the Trans-Siberian Railway in Development of cooperation between the Countries of Asian-Pecific Region. Journal of the Korean Society of Railways. pp. 24-29.

Bardal A.B. (2007) "Transkorejskaya zheleznodorozhnaya magistral" (The Trans-Korean Railway), Problemy Dal'nego Vostoka, No 4., pp.70-85.

Bin Ning, Tao Tang, Ziyou Gao, Fei Yan, Fei-Yue Wang, Daniel Zeng (2006), "Intelligent Railway Systems in China”, IEEE Intelligent Systems, vol. 21, no. 5, pp. 80-83, Sep./Oct. 2006, doi:10.1109/MIS.2006.99

Brooks, D. H. (2008) "Linking Asia's Trade, Logistics, and Infrastructure", ADBI Working Paper 128. Tokyo: Asian Development Bank Institute, 2008. Available at: http://www.adbi.org/workingpaper/2008/12/31/2796.linking.asia.trade.logistics. infrastructure

China Chamber of International Trade (CCOIC). Available at: http://www.ccpit.org/infosystem/index_en.jsp (accessed October 2009). 
China Railway Express Co., Ltd. : http:/www.cre.cn/creweb/index.jsp

Chinese Railways. Available at: http://railwaysofchina.com/statistics.html (accessed October 2009).

Chinese Statistical Yearbook 2008. Available at: http://www.stats.gov.cn/tjsj/ndsj/2008/indexeh.htm CIA World Factbook Available at: http://www.cia.gov

Djankov, S., Freund, C. and Pham, C.S. (2005) "Trading on time", Mimeo, World Bank. Available at: http://espanol.doingbusiness.org/Documents/TradingOnTime_APR08.pdf Enciklopedia Krugosvet. 20 November 2009. Available at: http://clicktour.ru/articles/63/1006375/1006375a3.htm

Encyclopedia of Rail Transport. Available at:

http://www.enciklopediajd.ru/razdel_02.2.8_kitajskie_jd.php

(accessed October 2009).

"Export Products of Kazakhstan. 2008”, KAZNEX (JSC “Corporation for Export Development and Promotion"). Available at:

http://www.kaznex.kz/about/about_us/Spravochnik_Eng4.pdf.

Foreign Investment and Foreign Trade Agency Mongolia,

http://www.investmongolia.com/index.php?sel=menu\&mnl=4_6\&PHPSESSID= 4b63de47811f3042594aee847f0c466c (accessed October 2009).

Hausman, W.H., Lee, L.L. and Subramanian, U. (2005) "Global logistics, services, supply chain metrics and bilateral trade patterns", Mimeo, World Bank, October.

Hong Kong Trade Development Council (HKTDC).

http://www.hktdc.com/info/mi/a/mpcn/en/1X06BV1E/1/Profiles-Of-China-

Provinces-Cities-And-Industrial-Parks/ (accessed September 2009).

Hummels D., (2009) "Trends in Asian Trade: Implications for Transport Infrastructure and Trade Costs". in Infrastructure's Role in Lowering Asia's Trade Costs: Building for Trade, edited by D.H. Brooks and D. Hummels. Cheltenham, UK: Edward Elgar Publishing.

Huziyatov T.D. (2008) "Ekonomicheskaya globalizaciya i problem nacional'noj I mezhdunarodnoj bezopasnosti" (Economic globalization and problems of national and international security), Problemy sovremennoj ekonomiki, № 2(26).

International Monetary Fund. Country Info. Available at:

http://www.imf.org/external/country/index.htm (accessed September 2009).

International Transport Forum. Available at: http://www.internationaltransportforum.org International Union of Railways. Available at: http://www.unic.org Itogovij doklad. Resultati analiza dannih, poluchennih v ramkah proekta NELTI v 2008-2009gg. Available at: http://www.iru-cis.ru/news/2009/PDF/final_report_rus.pdf. NELTY

JSC “Kazakhstan Temir Zholy National Enterprise". Available at: http://www.railways.kz (accessed October 2009)

JSC “Russian Railways". Available at: http://www.rzd.ru (accessed October 2009). 
Korea International Trade Association (KITA) http://www.kita.net

Korea Railroad Research Institute. Available at: http://www.krri.re.kr/krri_2008/publications/index.html Korea Trade-Investment Promotion Agency (KOTRA). Available at: http://www.kotra.co.kr Korea Transport Institute. Available at: http://english.koti.re.kr Lee Jae-Young (2004) "Iron Silkroad: Prospects for a Landbridge through Russia from Korea to Europe", Post-Soviet Affairs, 2004, 20, 1, pp.83-105.

Logistics in Korea. Emerging Investment Opportunities (2009). MLTN.

Ministry of Commerce of China. Available at: http:/www.mofcom.gov.cn/

(accessed October 2009).

Ministry of Commerce P.R. China. Invest in China. Available at:

http://www.fdi.gov.cn/pub/FDI_EN/default.htm (accessed October 2009).

Ministry of Land, Transport and Maritime Affairs of Republic of Korea. http://www.mltm.go.kr Ministry of Transportation of Russian Federation. http://www.mintrans.ru

(accessed October 2009).

Mongolian Railway Company. Available at: http://www.mtz.mn/\#

Na Hee-Seung (2004) "State of Works on the Reconstruction of Trans-Korean Railway and its Linkage with the Trans-Continental Railways", Korea Railroad Research Institute.

$\mathrm{Na}$ Hee-Seung (2007) "Strategy of Trans-Korean railway Transportation and Development of International Corridors", Korea Railroad Research Institute.

National Statistical Office of Mongolia. Available at: http://www.nso.mn/v3/index.php\# (accessed September 2009).

Nekhoroshkov V.P. (2009) "Integration of the TS and TK Railways", Journal of the Korean Society of Railways, pp.20-23.

Organization for Railways Cooperation, OSJD Committee. Available at: http://www.osjd.org (accessed September 2009).

Park J.M. (2006) “Ocenka social'no-ekonomicheskih posledsvij soedineniya Transkorejskoj I Transsibirskoj zheleznodorozhnih magistralej” (Evaluation of socio-economic effects of the Trans-Korean and Trans-Siberian Railways' Connection).

Regions of Russian Federation. Main characteristics of Federal Subjects of Russian Federation - 2008. Federal State Statistics Service of Russian Federation. Available at: http://www.gks.ru/bgd/regl/b08_14s/Main.htm

Rosgranica nazvala samie obustroennie punkti propuska. Rosbalt. 23/09/2009. Available at: http://www.rosbalt.ru/2009/09/23/674106.html

State Administration for Industry and Commerce of China. Available at: http:/www.saic.gov.cn/ (accessed October 2009).

Tennenbaum J. (2001) "The new Eurasian land-Bridge - infrastructure takes shape". Schiller Institute. November 2, 2001.

The Agency of Statistics of the Republic of Kazakhstan. Available at: http://www.stat.kz/publishing. (accessed September 2009). 
The Heritage Foundation. Index of Economic Freedom: Link Between Economic Opportunity and Prosperity. Available at: http://www.heritage.org/Index/Default.aspx (accessed in October 2009).

Tsuji Hisako (2002) "Japan and the ROK's Involvement in International Container Transportation Using the TSR", ERINA Report, Vol. 46, June 2002.

Tsuji Hisako (2003) "Growing International Use of the Trans-Siberian Railway: Japan is Being Left Out of the Loop". ERINA Discussion Paper.

Tsuji Hisako (2004) "A Competitive Environment for Linking the TSR\&TKR", ERINA Discussion Paper No.0409e. December 2004.

Tsuji Hisako (2007) "The Expanding Trans-Siberian Railway International Container Transport: the Anticipated Revival in Japanese Cargo", ERINA Discussion Paper, No.0701e, March 2007.

UN Conference on Trade and Development. World Investment Report 2008.

http://www.unctad.org/sections/dite_dir/docs/wir08_fs_mn_en.pdf(accessed September 2009).

UNESCAP (1996) "Trans-Asian Railway Route Requirements: Development of the Trans-Asian Railway in the Indo-China and ASEAN Subregion". Vol. 3, 1996. Available at: http://www.unescap.org/publications/detail.asp?id=691

UNESCAP. Development of Asia-Europe Rail Container Transport Through Block-trains:

Northern Corridor of the Trans-Asian Railway,1999. Available at:

http://www.unescap.org/publications/detail.asp?id=553

UNESCAP. Trans-Asian railway and the Issue of Break-off-gauge. Bangkok, Thailand.

Available at:

http://www.unescap.org/ttdw/common/TIS/TAR/break_of_gauge.asp

United Nation Economic and Social Commission for Asia and the Pacific Transport and

Tourism Division, Available at:

http://www.unescap.org/ttdw/common/TIS/TAR/Container\%20Block-trains.asp \#Steering (accessed October 2009).

United Nations. Commodity Trade Statistics Database (COMTRADE). New York. Available at: http://comtrade.un.org/db/default.aspx (accessed October 2009).

Uyanayev S. (2008) "Transportation Routes in Asia: Opportunities and Challenges for Russia", Executive Intelligence Review, January 2008, pp.38-41.

Whiteing T., Menaz B. (2009) "Rail Transport". Thematic Research Summary. Transport Research Knowledge Center.

World Economic Forum. Available at: http://www.weforum.org/en/media/publications/index.htm (accessed October 2009). 


\section{APPENDIX}

\section{Table 1.}

Provinces/States selected for Adjacent Regions

\begin{tabular}{l|l|l}
\hline \multicolumn{1}{c|}{ Russia } & \multicolumn{1}{c}{ China } & \multicolumn{1}{c}{ Kazakhstan } \\
\hline \hline Primorskiy Krai, & Liaoning & Almatinskaya Oblast \\
Khabarovskiy Krai, & Jilin & Vostochno-Kazakhstanskaya Oblast \\
Jewish Autonomous Oblast, & Heilongjian & Karagandinskaya Oblast \\
Chitinskaya Oblast, & Inner Mongolia & Astana \\
Buryat Republic, & Tianjin & Akmolinskaya Oblast \\
Ust'-Ordynsky Buryatskij & Beijing & North-Kazakhstan Oblast \\
Autonomous Region, & Hebei & \\
Irkutskaya Oblast, & Henan & \\
Krasnoyarsk Krai, & Shaanxi & \\
Novosibirsk Oblast, & Gansu & \\
Omsk Oblast, & Xinjiang & \\
Tyumen Oblast, & & \\
Sverdlovsk Oblast, & & \\
Perm Krai, & & \\
Kirov Oblast, & & \\
Yaroslavl Oblast, & & \\
Moscow Oblast, & & \\
Moscow & & \\
\hline
\end{tabular}

Source: Wikipedia: Online Encyclopedia 